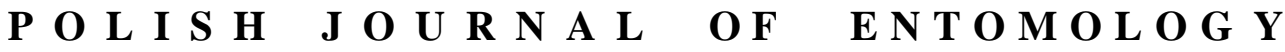

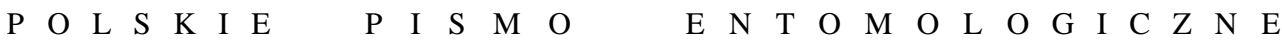

VOL. 87: 165-176

Lublin

30 June 2018

DOI: $10.2478 /$ pjen-2018-0012

\section{Evaluation of different insecticides for the management of onion thrips (Thrips tabaci LINDEMAN, 1889) (Thysanoptera, Thripidae) on onion (Allium cepa L.) crops}

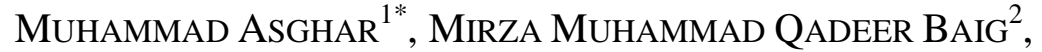 \\ MUHAMMAD AFZAL ${ }^{3}$, NAEEM FAISAL ${ }^{1}$ \\ ${ }^{1}$ office of Deputy Director (PP) Adaptive Research, DC Road, Gujranwala, Pakistan \\ ${ }^{2}$ office of Assisstant Director of Agriculture (Extension), DC Road, Gujranwala, Pakistan \\ ${ }^{3}$ University College of Agriculture, University of Sargodha, Sargodha, Pakistan
}

\begin{abstract}
The efficacy of five insecticides containing a.i. bifenthrin, dimethoate, spinosad, spinetoram and chlorfenapyr was evaluated following RCBD against Thrips tabaci in farmer's field for two consecutive years. The data were recorded before and after $24 \mathrm{~h}, 48 \mathrm{~h}, 72 \mathrm{~h}$ and 7 days of spraying. The results showed that all the insecticides reduced thrips populations compared to controls. However, the maximum reduction in thrips population and highest onion bulb yield (34.07 $\mathrm{t} / \mathrm{ha}$ ) was obtained with dimethoate 40EC followed by bifenthrin 10EC (33.14 t/ha). The minimum onion bulb yield (25.71 t/ha) was obtained in the control, where no insecticide was applied against thrips. If onion thrips are not controlled, the damage they cause can reduce bulb yields by $9-25 \%$. The highest incremental return over the control (Rs.83, 600/ha), net income (Rs.82, 913/ha) and maximum cost benefit ratio were also obtained in the treatment with dimethoate $40 \mathrm{EC}$.
\end{abstract}

KEY WORDS: Insecticides, onion, thrips, CBR, efficacy, dimethoate, bifenthrin, chemical control.

\section{INTRODUCTION}

The onion (Allium cepa L.) is the most important vegetable crop and is grown all over the world. It is called "queen of the kitchen" and is used all the year round.(SELVARAJ 1976, PATEL et al. 2009). In Punjab, Pakistan, the onion is grown mainly in the districts of Kasur,

\footnotetext{
* Corresponding author: miang786@yahoo.com
} 
Gujranwala, Sheikhupura, Vehari, Khaneawal, D.G. Khan and Jhang (ANONYMOUS 2015). The incidence of pests and diseases is the main factor limiting the higher production of onion crops. These are attacked by various pest insects: among them, the onion thrips, Thrips tabaci LindEMAN, 1889 (Thysanoptera: Thripidae), is the most injurious and important one (RAHMAN \& BATRA 1945, Vevai \& TALGERI 1948). Onion thrips are cosmopolitan and polyphagous (Kadri \& Goud 2006). Onion crop is mainly attacked by onion thrips when the crop is approaching maturity. Immature and adult thrips prefer to feed on young leaves in the inner necks of onion plants (ALSTON \& DROST 2008). Their feeding may aid the expansion of deadly purple blotch disease (ARANTHA 1980, ADILAKSHMI et al. 2008). Silvery areas on leaves are formed as a result of their feeding. The attacked leaves become curled, wrinkled and gradually dry up. When infestation is severe, the size of the bulbs is reduced. Heavily infested plants do not form bulbs, neither do the flowers produce seed (ATWAL 1976). Both nymphs and adults cause severe damage to the crop, which can reach 40-60\% in foliage damage and can lead to $10-20 \%$ yield losses annually (WAIGANJO et al. 2008, HAJDU \& NAGYIMRE 1984). Moreover, attack of purple blotch disease may increase as a result of damage caused by their feeding (ARANTHA 1980, ADILAKSHMI et al. 2008).

Insecticides are a major tool for thrips control, but this strategy is inadequate and unsustainable (MANIANIA et al. 2003) because the thrips have developed resistance to various groups of insecticides (LEBEDEV et al. 2013). Farmers have intensively used particularly those insecticides which are used to control this pest on cotton crops. The haphazard and repeated application of the same group of insecticides could have led to the development of resistance to insecticides (ShITOLE et al. 2002, ALSTON \& DROST 2008). The development of resistance in onion thrips to the most commonly used insecticides has also been reported by MARTIN et al. (2003). This causes farmers to use insecticides even more intensively, which ultimately leads to the problems of pest resurgence as a result of the destruction of beneficial fauna, environmental pollution, increases in production costs and pesticide residues in food (ADILAKSHMI et al. 2008).

As there are a few labelled insecticides that do ensure effective and consistent control of this notorious pest if used with due care and at the appropriate times. This study was, thus, undertaken to evaluate the efficacy of newly introduced and previously registered insecticides for the management of onion thrips during the winter season at minimum cost. 


\section{MATERIALS AND METHODS}

\section{Study sites and experimental plots}

The experiment to evaluate different insecticides for the control of thrips on onions was carried out at two sites: During Rabi in 2014-15 and 2015-16 in the farmers' field, managed by the farmers themselves, in Gujranwala Division in 2015-16. The distance between the sites in each year was not less than $30 \mathrm{~km}$. The experiment was followed by Randomized Complete Block Design (RCBD) with six treatments and three repeats at both sites. The treatments are listed in Table 1.

Table 1. Insecticides with brand name, active ingredients and recommended doses.

\begin{tabular}{clllc}
\hline Treatment & Insecticide & \multicolumn{1}{c}{$\begin{array}{c}\text { Active } \\
\text { ingredient }\end{array}$} & Manufacturer & $\begin{array}{c}\text { Dose } \\
{[\mathbf{m l} / \mathbf{h a}]}\end{array}$ \\
\hline T1 & Control & - & - & - \\
T2 & Silk 10EC & bifenthrin & 4B Group, Pakistan & 625 \\
T3 & Casper 40EC & dimethoate & Allah Din Group of companies, Pakistan & 625 \\
T4 & Tracer 240SC & spinosad & Dow Agro Sciences, USA & 150 \\
T5 & Radiant 120SC & spinetoram & Dow Agro Sciences, USA & 150 \\
T6 & Pirate 360SC & chlorfenapyr & BASF, USA & 250 \\
\hline
\end{tabular}

The net plot size for each treatment was $10 \times 8 \mathrm{~m}$. The onion nursery of the same cultivar was sown in mid-October of each year and transplanted on attaining the age of 45 days to the ridges. The ridges were $30 \mathrm{~cm}$ apart with two rows of onion plants at their tops. These rows were $20 \mathrm{~cm}$ apart from each other with a $10-\mathrm{cm}$ plant to plant distance. All agronomic practices were kept the same for all the treatments except applications of the insecticides to be tested for the control of thrips. No other insecticides were used. For the control of onion blotch difenoconazole+azoxystrobin 32.5SC @ $50 \mathrm{ml} /$ ha was also applied uniformly to all the treatments.

\section{Data collection and analysis}

Pre-treatment population data of onion thrips were recorded at regular weekly intervals from ten randomly selected plants in each replicate and the numbers of thrips present in each treatment were visually counted and averaged to obtain the mean population for each replicate (DIN et al. 2016). When the thrips population had reached ETL i.e. 30 thrips/plant (BurIRo et al. 2006, ShIBERU 2014, BESSIN 2017, Alston \& Drost 2008), the insecticide 
treatments were applied with the help of a knapsack sprayer after calibration. It took about 100 days for the pest to reach ETL after nursery transplantation to the main field.

In order to count the thrips population in each replicate, three spots were selected randomly and the thrips population counted at each spot on ten consecutive plants, thereby making a total of ninety plants for each insecticide tested. The thrips population was recorded before application of treatments, followed by intervals of $24 \mathrm{~h}, 72 \mathrm{~h}$ and 7 days after spraying (DIN et al. 2016). The onion bulb yields were recorded at the time of harvesting in the field using an electronic scale. Onion samples were also sent for pesticide residue analysis at the Pesticides residue laboratory Kala Shah Kaku.

\section{Statistical analysis}

The data were analysed using "Statistics" software. The significant differences among means were compared using the DMR test. The efficacy and yield gain percentages were calculated by using the following formulae given by SHIBERU \& NEGERI (2014).

$$
\begin{gathered}
\text { Efficiacy [\%] }=\frac{\text { Pre-spray count }- \text { Posts-spray count }}{\text { Pre-spray count }} \times 100 \\
\text { Yield gain [\%] }=\frac{\text { Protected treatment }- \text { Untreated treatment }}{\text { Protected treatment }} \times 100
\end{gathered}
$$

\section{Pesticide residue analysis}

The pesticide residues in onion bulbs were analysed using a GCMS-Agilent set-up at the pesticide residue laboratory in Kala Shah Kaku, district Sheikhupura.

\section{RESULTS}

The population of the thrips (nymphs and adults) was recorded just before application of treatments followed by intervals of $24 \mathrm{~h}, 72 \mathrm{~h}$ and 7 days after spraying. It ranged from 26.20 to 36.88 thrips per plant prior to treatment application (Table 2).

\section{Efficacy of insecticides against onion thrips}

The data on the effectiveness of different insecticides against thrips in onion crops are presented in Tables 3 and 4.

The data show significant differences among the performances of the insecticides tested. Insecticides containing bifenthrin 10EC and dimethoate 40EC proved to be significantly effective against thrips with minimum numbers (16.69 and 14.95) of thrips per plant 24 $\mathrm{h}$ after spraying with respective mortalities of $54.71 \%$ and $50.26 \%$. They were followed by 
chlorphenapyr $360 \mathrm{SC}$ and spinetoram $120 \mathrm{SC}$ with $14.46 \%$ and $14.83 \%$ mortality of thrips, respectively. spinosad 240SC proved to be the least effective against thrips with $41.96 \%$ mortality. In the control, by contrast, there was a $9.55 \%$ increase in the thrips population.

Table 2. Pre-treatment population density of onion thrips/plant for 2014-15 and 2015-16.

\begin{tabular}{clccc}
\hline \multirow{2}{*}{ Treatment } & \multirow{2}{*}{ Active ingredient } & \multicolumn{3}{c}{ Thrips population } \\
\cline { 3 - 5 } & & $\mathbf{2 0 1 4 - 1 5}$ & $\mathbf{2 0 1 5 - 1 6}$ & Mean \\
\cline { 3 - 5 } T1 & control & $40.96 \mathrm{a}$ & $29.95 \mathrm{a}$ & $35.46 \mathrm{a}$ \\
& & $(6.44)$ & $(5.52)$ & \\
T2 & bifenthrin & $37.66 \mathrm{ab}$ & $36.10 \mathrm{a}$ & $36.88 \mathrm{a}$ \\
& & $(6.18)$ & $(6.05)$ & \\
T3 & dimethoate & $33.20 \mathrm{bc}$ & $26.25 \mathrm{a}$ & $29.73 \mathrm{a}$ \\
& & $(5.81)$ & $(5.17)$ & \\
T4 & spinosad & $44.10 \mathrm{a}$ & $26.65 \mathrm{a}$ & $35.38 \mathrm{a}$ \\
& & $(6.68)$ & $(5.21)$ & \\
T5 & spinetoram & $25.93 \mathrm{c}$ & $39.00 \mathrm{a}$ & $32.47 \mathrm{a}$ \\
& & $(5.14)$ & $(6.28)$ & \\
T6 & chlorfenapyr & $26.80 \mathrm{c}$ & $25.60 \mathrm{a}$ & $26.20 \mathrm{a}$ \\
& & $(5.22)$ & $(5.11)$ & \\
& LSD & 6.535 & 18.681 & 18.955 \\
& CV & 10.33 & 23.76 & 22.56 \\
& F & 12.92 & 1.22 & 0.61 \\
& P & 0.0004 & 1.41 & 0.69 \\
\hline
\end{tabular}

Means followed by the same letter in a column are not significantly different.

Figures in parentheses are $\sqrt{ } \mathrm{x}+0.5$ transformed values.

The data 72 hours after treatment application show that mortality reached $91.94 \%$ and $85.23 \%$ with bifenthrin 10EC and dimethoate 40EC respectively (Table 4). These treatments were statistically on a par with each other. spinosad 240SC and spinetoram 120SC also gave thrips control over $75 \%$ and were also statistically on a par with each other. Chlorphenapyr 360SC proved the least effective in controlling thrips with only $63.13 \%$ mortality. This means that all the treatments behaved in the same fashion against the pest. In the control plot, the pest population again increased by $20.28 \%$. Therefore, all the insecticides tested proved significantly superior to the untreated control. 


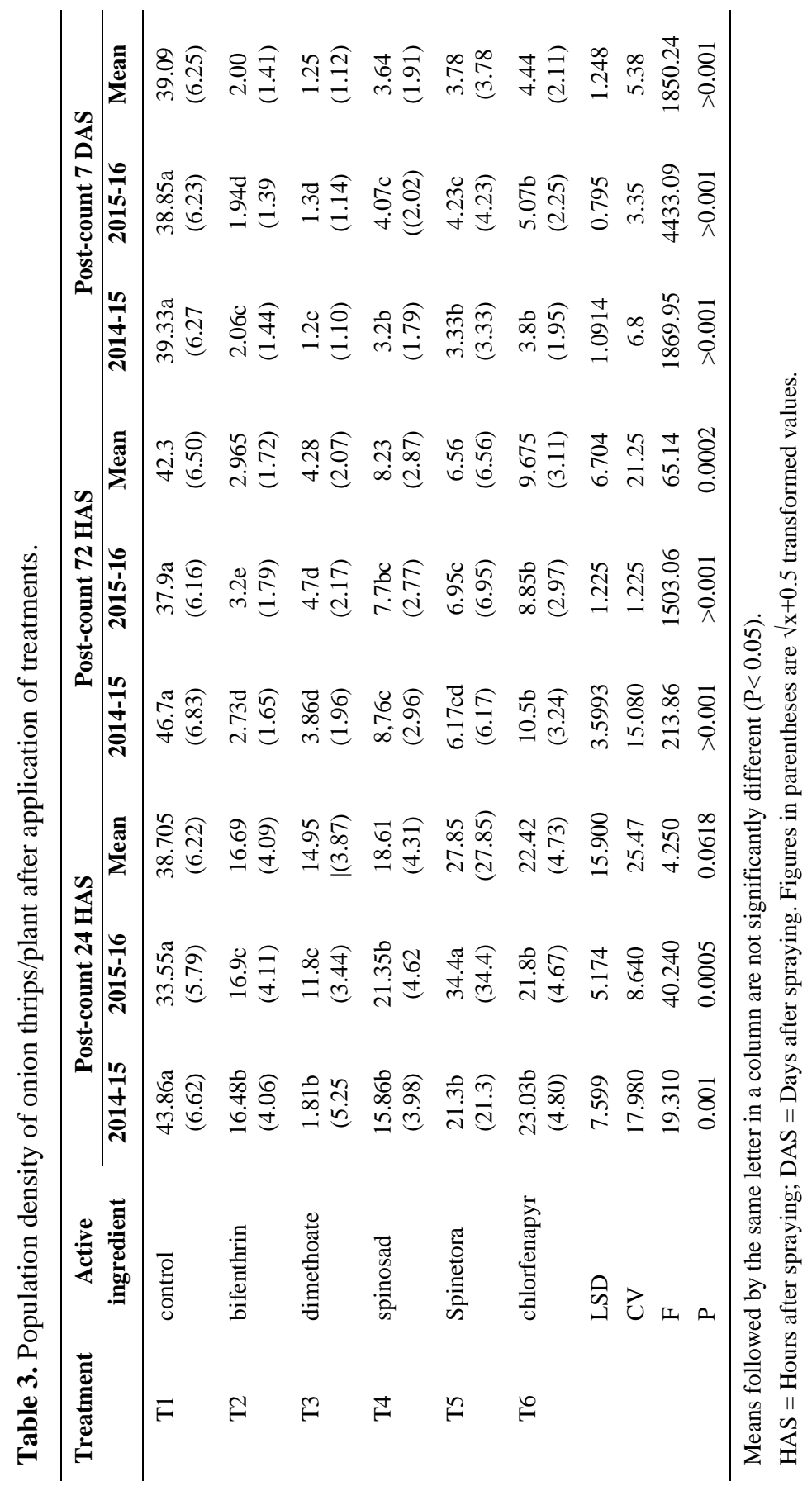




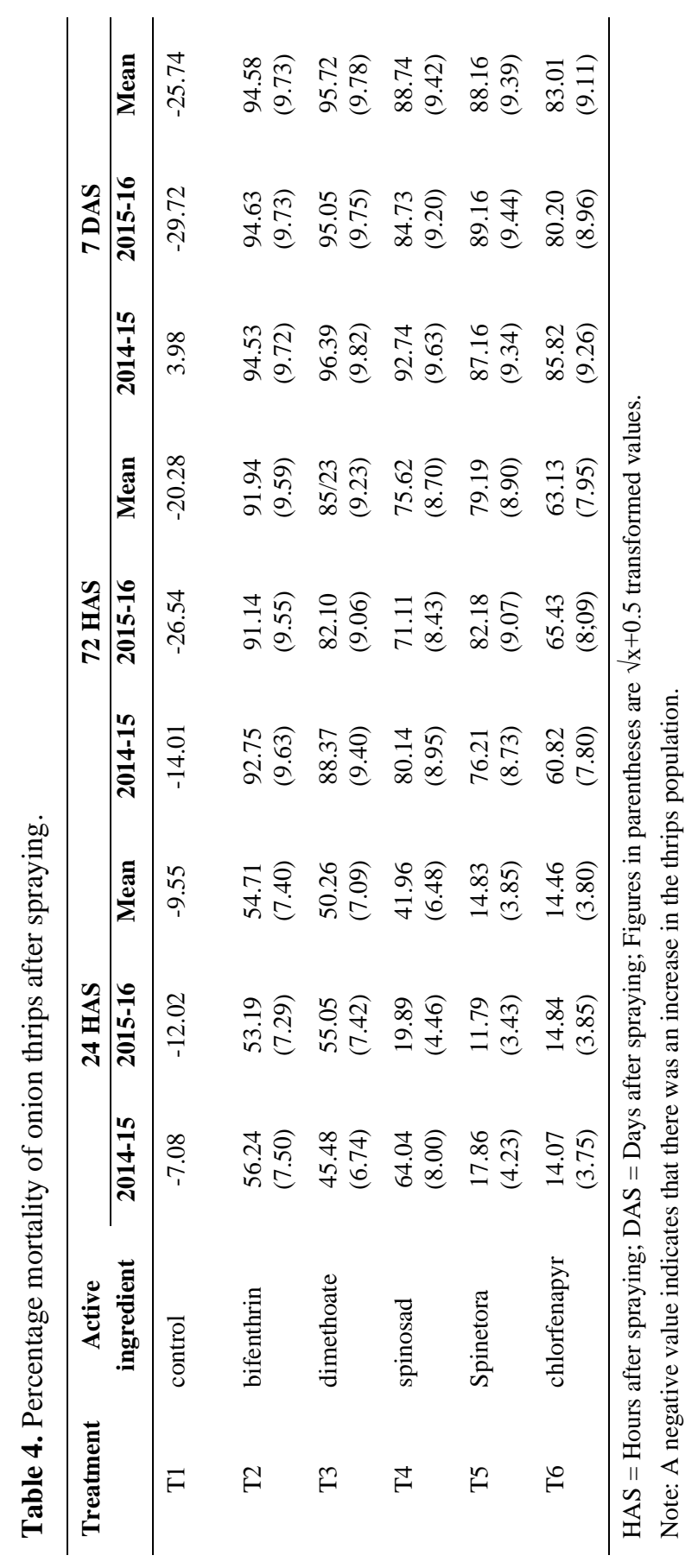


However, at 7 DAS, the mortality caused by dimethoate 40EC (95.72\%) was slightly higher than with bifenthrin 10EC (94.58\%) (Table 4). But again, these were statistically on a par with each other (Table 3). Among the other three insecticides, spinosad 240SC proved useful with $88.74 \%$ mortality, followed by spinetoram 120SC (88.16\%) and chlorphenapyr $360 \mathrm{SC}(83.01 \%)$. On the other hand, there was a $25.74 \%$ increase in the thrips population in the control plot. In this way all the treatments were significantly superior to the untreated control and caused more than $80-95 \%$ mortality of thrips.

\section{Effect of insecticide application on onion bulb yield}

The yield differences among the treatments were significant during each year of the study (Table 5).

Table 5. Effect of insecticide application on onion bulb yield and yield gain percentage.

\begin{tabular}{|c|c|c|c|c|c|c|c|}
\hline \multirow[t]{2}{*}{ Treatment } & \multirow{2}{*}{$\begin{array}{c}\text { Active } \\
\text { ingredient }\end{array}$} & \multicolumn{3}{|c|}{ Onion bulb yield $t / h a$} & \multicolumn{3}{|c|}{ Yield gain (\%) } \\
\hline & & 2014-15 & 2015-16 & Mean & 2014-15 & 2015-16 & Mean \\
\hline $\mathrm{T} 1$ & control & $\begin{array}{l}26.35 \mathrm{c} \\
(5.18)\end{array}$ & $\begin{array}{c}25.07 \mathrm{~d} \\
(5.06)\end{array}$ & $\begin{array}{l}25.71 \mathrm{~d} \\
(5.12)\end{array}$ & - & - & - \\
\hline $\mathrm{T} 2$ & bifenthrin & $\begin{array}{c}33.59 \mathrm{a} \\
(5.84)\end{array}$ & $\begin{array}{c}32.69 \mathrm{a} \\
(5.76)\end{array}$ & $\begin{array}{c}33.14 \mathrm{a} \\
(5.80)\end{array}$ & $\begin{array}{l}21.55 \\
(4.70)\end{array}$ & $\begin{array}{l}23.31 \\
(4.88)\end{array}$ & $\begin{array}{l}22.43 \\
(4.79)\end{array}$ \\
\hline $\mathrm{T} 3$ & dimethoate & $\begin{array}{c}34.1 \mathrm{a} \\
(5.88)\end{array}$ & $\begin{array}{c}34.04 \mathrm{a} \\
(5.88)\end{array}$ & $\begin{array}{c}34.07 \mathrm{a} \\
(5.88)\end{array}$ & $\begin{array}{l}22.73 \\
(4.82)\end{array}$ & $\begin{array}{l}26.35 \\
(5.18)\end{array}$ & $\begin{array}{l}24.54 \\
(5.00)\end{array}$ \\
\hline $\mathrm{T} 4$ & spinosad & $\begin{array}{c}30.98 \mathrm{~b} \\
(5.61)\end{array}$ & $\begin{array}{c}29.15 \mathrm{~b} \\
(5.45)\end{array}$ & $\begin{array}{c}30.07 \mathrm{~b} \\
(5.53)\end{array}$ & $\begin{array}{l}14.95 \\
(3.93)\end{array}$ & $\begin{array}{l}14.00 \\
(3.81)\end{array}$ & $\begin{array}{l}14.47 \\
(3.87)\end{array}$ \\
\hline T5 & spinetoram & $\begin{array}{c}30.44 b \\
(5.56)\end{array}$ & $\begin{array}{c}29.04 \mathrm{~b} \\
(5.44)\end{array}$ & $\begin{array}{c}29.74 b \\
(5.50)\end{array}$ & $\begin{array}{l}13.44 \\
(3.73)\end{array}$ & $\begin{array}{l}13.67 \\
(3.76)\end{array}$ & $\begin{array}{l}13.55 \\
(3.75)\end{array}$ \\
\hline \multirow[t]{5}{*}{ T6 } & chlorfenapyr & $\begin{array}{c}29.17 b \\
(5.45)\end{array}$ & $\begin{array}{c}27.16 \mathrm{c} \\
(5.26)\end{array}$ & $\begin{array}{l}28.17 \\
(5.35)\end{array}$ & $\begin{array}{c}9.67 \\
(3.19)\end{array}$ & $\begin{array}{c}7.70 \\
(2.86)\end{array}$ & $\begin{array}{c}8.68 \\
(3.03)\end{array}$ \\
\hline & LSD & 1.9373 & 1.361 & 1.279 & - & - & - \\
\hline & $\mathrm{CV}$ & 3.46 & 1.79 & 1.65 & - & - & - \\
\hline & $\mathrm{F}$ & $21 / 83$ & 80.21 & 77.77 & - & - & - \\
\hline & $\mathrm{P}$ & $>0.001$ & 0.0001 & 0.0001 & - & - & - \\
\hline
\end{tabular}

Means followed by the same letter in a column are not significantly different $(\mathrm{P}<0.05)$.

Figures in parentheses are $\sqrt{x}+0.5$ transformed values.

With dimethoate 40EC the yield recorded was significantly higher $(34.07 \mathrm{t} / \mathrm{ha})$ than with the other insecticides tested. This was statistically on a par with bifenthrin 10EC (33.14 t/ha), followed by spinosad 240SC (30.07 t/ha), spinetoram 120SC (29.74 t/ha) and chlorphenapyr 360SC (28.17 t/ha). Therefore, with the use of dimethoate for the control of 
thrips on onion crops, there was a $24.25 \%$ increase in yield, followed by bifenthrin $10 \mathrm{EC}$ with a $22.42 \%$ yield increase. The lower yield ( $28.17 \mathrm{t} / \mathrm{ha})$ was obtained in chlorphenapyr $360 \mathrm{SC}$ which was even $8.67 \%$ higher than that of control (25.71 t/ha). The yield from the control plot was significantly low than from all the other tested insecticides.

\section{The economics of insecticides}

The data regarding economic returns (Table 6) revealed that the highest returns (Rs. 83,600/ ha), net income (Rs. 82,913/ha) and the highest cost benefit ratio (CBR) was obtained with dimethoate 40EC, followed by bifenthrin 10EC, spinetoram 120SC, spinosad 240SC and chlorphenapyr 360SC.

Table 6. Effect of various treatments against onion thrips on monetary returns and CBR. MY - Mean yield [Kg/ha]; Inc - Income [Rs.10/kg]; Cost - Cost of pesticide; IR - Incremental return over control; ENB - Estimated net benefit [Rs/ha].

\begin{tabular}{|c|l|c|c|c|c|c|c|}
\hline Treatment & \multirow{2}{*}{ Insecticide } & MY & Inc & Cost & IR & ENB & CBR \\
\cline { 3 - 8 } & & A & B & C & D & E(D-C) & F(D/C) \\
\hline T1 & control & 25710 & 257100 & 0 & 0 & 0 & 0 \\
\hline T2 & bifenthrin & 33140 & 331400 & 1187.50 & 74300 & 73112.50 & $1: 62.57$ \\
\hline T3 & dimethoate & 34070 & 340700 & 686.88 & 83600 & 82913.13 & $1: 121.71$ \\
\hline T4 & spinosad & 30065 & 300650 & 3781.88 & 43550 & 39768.13 & $1: 11.52$ \\
\hline T5 & spinetoram & 29740 & 297400 & 2919.38 & 40300 & 37380.63 & $1: 13.80$ \\
\hline T6 & chlorfenapyr & 28165 & 281650 & 3437.50 & 24550 & 21112.50 & $1: 7.14$ \\
\hline
\end{tabular}

*Cost of pesticides also included application charges.

**(gross income of the treatment-gross income from the control)

\section{DISCUSSION}

The results indicated that dimethoate proved to be the best insecticide for the control of thrips, followed by bifenthrin10EC, whereas chlorphenapyr 360SC exhibited the weakest action against thrips. However, the pooled data revealed that all the insecticidal treatments were significantly effective for the control of onion thrips on onion crops. Thus, the results obtained in this study are quite in conformity with those of ZAMAN (1989), who showed that bifenthrin e.c., carbosulfan e.c., cypermethrin e.c., deltamethrin+triazophos e.c. and dimethoate e.c. reduced the Thrips tabaci Lind., population for more than 2 weeks. In contrast, SHELTON et al. (2008) showed that acetamiprid, dimethioate, spinosad and imidacloprid performed better than lambda-cyhalothrin against thrips on cabbage. ULLAH et 
al. (2010) sprayed Thiodan, Confidor, Tracer, Megamos and Actara for the control of thrips on onion crops. Except for Actara, all the other insecticides were significantly effective against the pest as compared to the control. The results of the present investigation are also in agreement with those of HUSSEIN et al. (2015), who found in two study seasons that application of carbosulfan 20EC and spinetoram 120SC reduces the population density of T. tabaci infesting garlic plants and gave the highest yield.

But the results of the present study are not in accordance with the research of KADRI \& GouD (2006), who evaluated that that acetamiprid 20SP was highly effective in reducing the population of onion thrips and in recording highest onion bulb yield in comparison with neem products and dimethoate.

It is quite clear from Table 5 that the damage due to onion thrips could reduce bulb yields by $9-25 \%$ compared with the control. These results are in agreement with those of IBRAHIM et al. (2015), who determined a significant difference in onion bulb yield by dimethoate 40EC, tree tobacco, Karate 5EC and Mexican marigold from the control. A bulb yield of $>30 \%$ was obtained in the tree tobacco and dimethoate treated plots compared with the control. These results also concur with those of MALIK et al. (2003), who indicated that thrips population densities have an indirect effect on onion yield.

The results presented in this paper are, however, partially in line with those of SHIBERU \& NEGERI (2014), who found that if the onion thrips population is not checked, the damage they cause can reduce bulb yields by $23-85 \%$. This indicated that onion thrips caused damage to the crop and resulted in lower yields when pest infestation remained above ETL (MAYER et al. 1987). Therefore, in the present study the control plot gave a minimum yield. The results are also partially in agreement with those of HUSSEIN et al. (2015), who obtained the highest yield of garlic with the application of carbosulfan 20EC and spinetoram 120SC against onion thrips. PATIL et al. (2009) found that treatment with deltamethrin 1EC+triazophos 35EC recorded a higher yield t/ha, which was statistically on a par with spinosad 45SC compared to the other treatments. PATEL \& PATEL (2012) indicated that deltamethrin $2.8 \mathrm{EC}$ recorded significantly higher bulb yields, followed by cypermethrin 10EC, diafenthiuron 50WP, bifenthrin 10Ec and profenophos 50EC, which were on a par with each other.

\section{CONCLUSION}

It is clear from the efficacy of insecticides and cost-benefit ratios that dimethoate 40EC and bifenthrin 10EC proved to offer the best protection against onion thrips. Moreover, no resistance against them has been reported after their having been successfully used for many years. Furthermore, the results from the pesticide residue analysis laboratory 
indicated that no residues of any of the insecticides used in this experiment were detected. Therefore, it can be concluded that dimethoate and bifenthrin can be safely used in rotation to avoid the resistance and thrips on onion crops once the pest has reached ETL.

\section{REFERENCES}

Adilakshmi A., Korat D.M., Vaishnav P.R. 2008. Bio-efficacy of some botanical insecticides against pests of Okra. Karnataka Journal of Agricultural Sciences 21(2): 290-292.

Alston D.G., Drost D. 2008. UTAH pests fact sheet. Onion thrips (Thrips tabaci). Internet: http://utahpests.usu.edu/IPM/files/uploads/PDFDocs/factsheet-pdf/ENT-117-08PR-unlocked.pdf (accessed on 3.05.2017)

ANONYMOUS 2015. All about /vegetables/onion. Internet: http://www.pakissan.com/english/all about/horticulture/vegetables/onion.shtml (accessed on 3.05.2017)

ARANTHA K.T.N. 1980. Thrips in vectors of plant pathogens. [in:] K.F. HARRIS, K. MARAMOROSCH (eds.). Vectors of Plant Pathogens. Academic Press, New York, 149-164.

Atwal A.S. 1976. Agricultural pests of India and South East Asia. Kalyani Publishers, Delhi.

BESSIN R. 2017. UK cooperative extension services. Thrips management with onions. Internet: https://entomology.ca.uky.edu/files/efpdf2/ef317.pdf (accessed on 03.05.2017)

Buriro A.S., Ali M.K., Jarwar A.D. 2006. Hand Book on safe and efficient use of Pesticides. Directorate General of Agricultural Research. Tandojam, Department of Agriculture Government of Sindh, Pakistan.

Din N., Ashraf M., HuSSAIN S. 2016. Effect of different non-chemical and chemical measures against onion thrips. Journal of Entomology and Zoology Studies 4(5): 10-12.

Hajdu J., NAGYimRe E. 1984. Control of onion foliage pests. Review of Agricultural Entomology 73(1): 902.

Hussein S.H.A., Hanafy A.R.I., Afsahand Maha A.F.E., Tantawy A.M. 2015. Optimal time for insecticide applications to reduce the onion thrips, Thrips tabaci population on garlic crop and their effect on resultant yield. Mansoura Journal of Plant Protection and Pathology 6(2): 291-300.

IBRAhim F., GEBRETSADKAN A., AYimUt K.M. 2015. Evaluation of botanicals for onion thrips, Thrips tabaci Lindeman, (Thysanoptera: Thripidae) control at Gum Selassa, South Tigray, Ethiopia. Momona Ethiopian Journal of Science 7(1): 32-45.

KADRI S., GOUD B. 2006. Efficacy of newer molecules of insecticides and botanicals against onion thrips, Thrips tabaci (LindemAn) (Thysanoptera: Thripidae). Karnataka Journal of Agricultural Sciences 19(3): 539-543.

Lebedev G., Abo-Moch F., Gafni G., Ben-YakiR D., Ghanim M. 2013. High-level of resistance to spinosad, emamectin benzoate and carbosulfan in populations of Thrips tabaci collected in Israel. Pest Management Science 69(2): 274-277.

MaLik M.F., NawaZ M., Hafeez Z. 2003. Inter and intra row spacing effects on thrips (Thrips spp.) population in onion (Allium cepa). Asian Journal of Plant Sciences 2(9): 713-715. 
Maniania N.K., Sithanantham S., Ekesi S., Ampong-Nyarko K., Baumgartner J., Lohr B., MatoKA C.M. 2003. A field trial of the entomogenous fungus Metarhizium anisopliae for control of onion thrips, Thrips tabaci. Crop Protection 22(3): 553-559.

Martin N.A., Workman P.J., Butler R.C. 2003. Insecticide resistance in onion thrips (Thrips tabaci) (Thysanoptera: Thripidae). New Zealand Journal of Crops and Horticultural Sciences 31(2): 99-106.

MAYER D.F., LundEN J.D., RATHBONE L. 1987. Evaluation of insecticides in the control of Thrips tabaci (Thysanoptera: Thripidae) and effects of thrips on bulb onions. Journal of Economic Entomology 80(4): 930-932.

Patel H.C., Patel J.J. 2012. Evaluation of conventional insecticides against thrips, Thrips tabaci LINDEMAN infesting onion (Allium cepa L.). AGRES 1(3): 268-273.

Patil S.D., Chandele A.G., Wayal C.B., Game B.C. 2009. Efficacy of different newer chemicals and bio-insecticides against onion thrips in kharif season. International Journal of Plant Protection 2(2): $227-230$.

RAhman K.A., BAtra A.L. 1945. The onion thrips, Thrips tabaci. L (Thripidae; Thysanoptera). Indian Journal of Agricultural Sciences 14(4): 308-310.

SelvaraJ S. 1976. Onion: Queen of kitchen. Kisan World 3(12): 32-34.

Shelton A.M., Plate J., Chen M. 2008. Advances in control of onion thrips (Thysanoptera: Thripidae) in cabbage. Journal of Economic Entomology 101(2): 438-443.

SHIBERU T.M.A. 2014. The importance and management option of onion thrips, Thrips tabaci (L.) (Thysanoptera: Thripidae) in Ethiopia: A review. Journal of Horticulture 1:2.

Shiberu T., Negeri M. 2014. Evaluation of insecticides and botanicals against onion thrips, Thrips tabaci (L.) (Thysanoptera: Thripidae). Entomology and Applied Science Letters 1(2): 26-30.

Shitole D.M., Shankar G., Mithyantha M.S. 2002. Evaluation of certain new insecticides against onion thrips. Pestology 26: 49-50.

Ullah F., Mulk M., Farid A., SAeed M.Q., Sattar S. 2010. Population dynamics and chemical control of onion thrips (Thrips tabaci LiNDEMANN). Pakistan Journal of Zoology 42(4): 401-406.

VeVai E J., TAlgeri G.M. 1948. Bombay crop pest calendar and a seasonal schedule of their control by modern insecticides. Journal of Bombay Natural History Society 48: 725-726.

Waiganjo M.M., MueKe J.M., Gitonga L.M. 2008. Susceptible onion growth stages for selective and economic protection from onion thrips infestation. Acta Horticulture 767: 193-200.

Zaman M. 1989. Effect of foliar insecticides against thrips on onion in Peshawar, Pakistan. Tropical Pest Management 35(3): 332-333.

Received: 24 May 2017

Accepted: 2 January 2018 